\title{
Unimplemented Policy against the Implementation of Madrasah Diniyah Takmiliyah Education in Barru Regency
}

\author{
Muhammad Fadli \\ Muhammadiyah University of Parepare \\ bakkalolonanepo@gmail.com
}

\author{
Nhelbourne K. Mohammad \\ Cotabato State University \\ nhelkm1980@gmail.com
}

\begin{abstract}
An implementation of madrasah diniyah takmiliyah education in Barru Regency as non-formal education institutions are considered not conducive. This is due to lack of coaching, facilities, infrastructure, educators, education personnel, learners, education programs, teaching and learning process, and financing. To overcome these problems, the Local Government of Barru Regency issued Regional Regulation Number 11 of the Year 2010 on Diniyah Takmiliyah Education. The government issued the Local Government Rules and Regulation No. 30 of 2012 about the Cost Assistance for the Implementation of Educational Diniyah Takmiliyah in Barru Ragency. This research is formulated to reveal the impact of policy implementation of educational diniyah takmiliyah to learners, institutions, and educators in the implementation of compulsory education. The research employs qualitative approach with descriptive analysis based on primary and secondary data source gathered from selected informants through interview and observation. The result of this research showed that the policy of Local Government of Barru Regency toward the development of students, institute, and educator have positive impact, but not significant. It occurred since madrasah diniyah certificate cannot be a required document to enter formal education, such as junior high school and madrasah tsanawiyah.
\end{abstract}

Keywords: Implementation, Madrasah, Diniyah Takmiliyah, Education, Barru Regency

\section{INTRODUCTION}

The objective of the National Education is to enhance the faith and devotion and the noble character of learners as stated in the 1945 Constitution, in Article 31, paragraph 3 that: "The government seeks and organizes a national education system, which to enhances the faith and devotion to the Almighty God and noble morals in order to educate the life of the nation, which is regulated by law [1]. To carry out the mandate, the government has established a national policy of education by enacting Law Number 20 of the Year 2003 on National Education System as the implementation of the Constitution [2]. The National Education System Act in Article 3 states that: "National education functions to develop the ability and form the character and civilization of dignified nation in order to educate the life of the nation, aiming for the development of potential learners in order to become human beings who believe and devotion to the Almighty God, noble, healthy, knowledgeable, capable, creative, independent, and become a democratic and responsible citizen." The government's policy towards Islamic education in Indonesia, legally-normative is contained in Government Regulation No. 55 of 2007 on Religious Education and Religious Education [3].

Based on these government regulations, diniyah education can be categorized into two: formal diniyah education and non-formal diniyah education [4]. Formal diniyah education presents science education that comes from the teachings of Islam. It is given at the level of early childhood education, primary education, secondary education, and higher education. Non-formal diniyah education is presents Pengajian Kitab, Majelis Taklim, Al-Qur'an Education, Diniyah Takmiliyah, or other similar forms (No. 55 the Year 2007, Article 16) [5]. During the period of regional autonomy, the functional role of Ministry of Religious Affairs (Kemenag) still has responsible fully for the existence, development, and development of Islamic education from central to regional [6]. However, the Ministry of Religious Affairs as a vertical institution may experience structural obstacles in providing assistance and supervision on religious education to madrasah diniyah institutions in the region. This constraint, that resulted in the existence of education diniyah takmiliyah in Barru Regency needs to get the same attention with formal education [7].

\section{METHOD}

The object of research is the impact of implementation of education policy Diniyah Takmiliyah in Barru Regency which lasted for threemonths, starting from July to September 2018. This case study focused on the implementation of education policy of Diniyah Takmiliyah. The sources of data derived from the research informants who have accountability. The informants come from the parties who have the authority and capability in their field, such as: 1) Elements of Regional Government of Barru Regency, Head of Legislation SubDivision at the Secretariat of Regional Government, 2) Ministry of Religious Affairs Office of Barru Regency, Head of Peka Pontren Section, 3) Elements of Education Office of Barru Regency, namely the Head of Basic Education Section, 4) Diniyah Takmiliyah Communication Forum of Barru 
Regency, and 5) Managers / Foundation of Islamic Education Madrasah Diniyah Takmiliyah.

Primary data were obtained from the research informants that had previously mentioned. (Informant Research). The secondary data were in the form of documents, books, and so on which consists of: 1) Barru Regent's Regulation No. 11 of 2010 on Education Diniyah Takmiliyah; and 2) Barru Regent's Regulation No. 38 of 2012 on Procedure of Providing Cost Assistance for Implementation of Diniyah Takmiliyah Education in Barru District. The data were collected though distributing questionnaire, interview, and focus group discussion (FGD) and field observation (survey) by the selected informants. The inductive analysis technique employs Yin, Seville, with the following steps: 1) research question, 2) research proposition, 3) research analysis unit, 4) the logic of data linkage with the proposition, and 5) criteria for interpreting the findings.

\section{RESULT}

The policy of Diniyah Takmiliyah education is generally regulated through a Regional Regulation. Implementation of its policy is controlled technically through the Regent Regulation. In this case, financing assistance for the implementation of Diniyah Takmiliyah education is provided. The theory of public policy stated that the policies, in the legislation form from public officials that have been published need to be evaluated in terms of implementation and policy impact. It must be done because the impact, either positive or negative depends on the subject and/or object. In this case, the subject of policy is the local government, the Agency and the Office of the Ministry of Religious Affairs of Barru Regency, while the object of policy is the organizers and implementers of education, the public in general, especially the students diniyah takmiliyah.

The impact of the implementation of the educational policy of diniyah takmiliyah can be known based on the results of a comprehensive evaluation of various aspects of education. The evaluation of diniyah takmiliyah education was carried out in order to control the quality of local education to learners, institutions and education program as a form of accountability of the implementation to the parties concerned. Evaluation is held to help the learning process, which in turn it can improve the learning outcomes. To see the impact of education policy, several elements were addressed, namely:a) learners, b) educational institutions, and c) educators.

\section{Participants}

As stated in the Regional Regulation in Article 24, the graduates of Diniyah Takmiliyah who are eligible in the learning process is given certificate and diploma. The diploma or certificate is given to the learner as a recognition and appreciation of student learning, while Diniyah Takmiliyah diploma can be used as one of the requirements to pursue further education to the level of takmiliyah wustha. The educational policy of Diniyah Takmiliyah requires the learners to participate in teaching and learning process to create children who believe, piety and have akhlakulkarimah. This education is considered only an additional or complementary religious education, which is assumed inadequate for elementary school students.
Based on the information, certificate or diploma of Diniyah Takmiliyah is not used as a requirement to continue to junior high school or madrasah tsanawiyah. Compulsory education is intended in the Regional Regulations and Regent's Regulations. It is not to obtain a certificate or diploma as a prerequisite for continuing education to junior high school. Besides, having an additional religious education is believed inadequate for students in elementary school. The policy, according to the opinion of the Chairman of the Ma'arif Islamic Educational Institute of Nahdatul Ulama (NU) in Barru Regency,Ustadz Dr. H. KamaruddinHasan is very weak because it does not encourage the learners to follow Diniyah Takmiliyah education as the initial idea of the declaration of Perda. Compared to the result of research on compulsory education diniyahaliyah in Bantaeng Regency, which the researcher visited last year, it can be said that diniyah education policy in Barru Regency is not as strong as that of in Bantaeng Regency.

In terms of the number of students, the number of madrasah students Diniyah Takmiliyah almost equal to the number of elementary students. This is because the certificate and diploma of madrasah Diniyah Takmiliyah in Bantaeng Regency is used as a requirement to pursue the next level of education, for example junior high school or madrasah tsanawiyah. Certainly, this phenomenon proved that the education policy on Diniyah Takmiliyah in Barru Regency has positive effect although it did not significantlyinfluence on the increasing number of Diniyah Takmiliyah students. To be clear, some diniyah education reported that there was no significant increase on the number of students after the enactment of Perda Diniyah Takmiliyah in Barru Regency. It may because the certificate and diploma of Diniyah Takmiliyah education is not a prerequisite to enter junior high school or madrasah tsanawiyah.

\section{Institutional Education}

An evaluation related to the components of educational institutions, such as educational facilities and infrastructure of Diniyah Takmiliyah needs to be provided. The evaluation included the ownership status of the institutional legal entity and the building used for the teaching and learning process. The teaching and learning activities processwas usually done in pondokpesantren, mandiri building, school building, mosque, musholla, or other eligible places. The result of this research found that the Diniyah Takmiliyah education in Barru Regency has not been maximally implemented in mandiri building which is built specifically for diniyah. Mandiri building was built by individuals or educational foundation. In addition, many teaching and learning process of Diniyah Takmiliyah was also held in institution of Islamic education. The participants came from students who attend elementary school nearby.

The teaching and learning process of Diniyah Takmiliyah education is also implemented in mosques and musholla. It happened whenthe school buildings and other places which were commonly used cannot accommodate the learning activity. Unlike the results of research on compulsory education madrasah diniyahaliyah in Bantaeng Regency. In this case, education facilities and infrastructure make use of many elementary school buildings. It had been mentioned that after the enactment of the Diniyah Regulation, the number of educational institutions Diniyah Takmiliyahin Barru regency 
increased, although the increase was not significant. The data from the Ministry of Religious Affairs stated that there were 1,086 students in 2011 ; it increased to 1,136 students in 2013. Thus, the difference of the increase was 50 (4.40).

A comparison of the number of institutions Diniyah Takmiliyah, has slightly increased. Even, in some district, there was no increasing number. In some other sub-districts, the average increase is only 1 to 4 students of eachmadrasah. Surely, this did not get along with the ideas of the community through Communication Forum Diniyah Takmiliyah who expected that madrasah Diniyah Takmiliyah became compulsory for elementary school students. With the nomenclature of such a regulation, although it has an impact on the improvement of educational institutions Diniyah Takmiliyah, it is not significant.

\section{Teachers' Power}

Educators at Diniyah Takmiliyah are the ones who conduct the task on teaching and learning process at Diniyah Takmiliyah. The teaching staff must have competence, good personality, professional, social pedagogic. Every educator has the right to: a) obtain income and social welfare guarantees, b) obtain career coaching based on work performance, and c) use facilities, infrastructure and educational facilities. Each educator is obliged to: a) carry out the task with full responsibility and devotion, b) enhance professionalism in line with the development of science, technology and nation-building, and c) maintain a good reputation in line with the trust given by the community.

The results of the research showed that the staff of Diniyah Takmiliyah education in Barru Regency were appointed by the Mayor of Barru Regency on the proposal from the Ministry of Religious Affairs and Education and Culture Office of Barru Regency. The educators should minimally have certificate of boarding schools, religious education schools and more preferably graduates of Islamic education under graduate programs. Mostly, the educator of Diniyah Takmiliyah education, 5,150 people, came from the graduates ofpondokpesantren. Only a small number of educators came from a college of Islamic education. In terms of salary, the educators were only earned IDR 900, 000 in three months. The income comes from the assistance of BAZ Barru Regency. In addition, there is also operational assistance from the District Government of Barru Regency. The amount of donation between educational institutions of Diniyah Takmiliyah varied: between IDR 5,000.000 every year. Of course, this income is very insufficient when it compared to the needs of everyday life. Therefore, teaching in diniyah education is only done for an additional job. Thus, the educators could not rely on this job since it could not stand the cost of their living. The amount of income can certainly affect the performance of educators in the learning process. Further, it might result in the ability of students in understanding the material-religious matter-which in turn, affect students' achievement.

\section{CONCLUSION}

Based on the result of the research, it can be concluded that the policy of Local Government Unit of Barru Regency toward students, institute, and educator have positive impact, but the increase of number it is not significant. It is because the compulsory study of madrasah Diniyah Takmiliyahand its diploma and certificate was not required as a requirement to enter a formal education level such as junior high school and madrasah tsanawiyah.

\section{REFERENCES}

[1] S. Saharudin, "Implementasi Metode Pembelajaran Berbasis Qurani Di Mts Al-Baqiyatusshalihat Nw Santong," El-Hikam Vol. Viii Nomor 1 Januari- Juni, 2015.

[2] M. L. T. Cossio Et Al., "Undang-Undang Republik Indonesia Nomor 20 Tahun 2003 Tentang Sistem Pendidikan Nasional," Uu Ri Nomor 20 Tahun 2003, 2012.

[3] Kementerian Pendidikan Nasional, Undang-Undang Republik Indonesia Nomor 20 Tahun 2003 Tentang Sistem Pendidikan Nasional. 2012.

[4] R. Indonesia, Undang-Undang Republik Indonesia Nomor 20 Tahun 2003 Tentang Sistem Pendidikan Nasional. 2003.

[5] Ah Pascasarjana Uin Maulana Malik Ibrahim Malang, "Membangun Karakter Guru Madrasah Tsanawiyah Salafiyah Syafi'iyah Sukorejo Situbondo," Jpii, 2016.

[6] Supriadin, "Politik Pendidikan Islam Di Indonesia: Analisis Sistem Pendidikan Pesantren Dan Madrasah," El-Hikmah, 2005.

[7] Akhmad Syahri, "Pengembangan Madrasah Unggulan Di Madrasah Diniyah Miftahul Huda Sumurpanggang Margadana Tegal Jawa Tengah," AlWijdáN J. Islam. Educ. Stud., 2017. 